Research Article

\title{
Friction and wear behavior of karanja oil derived biolubricant base oil
}

\author{
Umesh Chandra Sharma ${ }^{1}$. Sadhana Sachan ${ }^{2}$
}

๑) Springer Nature Switzerland AG 2019

\begin{abstract}
This work deals with the tribological performance of karanja oil trimethylolpropane ester (KOTMPE) biolubricant base oil for its probable application as automotive lubricant. The biolubricant was synthesized by transesterification of karanja oil methyl ester with trimethylolpropane (TMP) under acid catalyst. The study was made with Ducom TR30L four-ball tester at 1200 rev $\min ^{-1}$ speed and $75^{\circ} \mathrm{C}$ temperature over 60 min duration under normal loads of $15 \mathrm{~kg}$ and $40 \mathrm{~kg}$ as per ASTM D 4172-94 A and B standard test method. Principal results at two loads are given here: Coefficient of friction (CoF) 0.100 and 0.042, wear scar diameter (WSD) $0.30 \mathrm{~mm}$ and $0.44 \mathrm{~mm}$, flash temperature parameter (FTP) 80.932 and 126.249, and thermal energy (TE) $0.054 \mathrm{~J}$ and $0.060 \mathrm{~J}$, respectively. The study found that KOTMPE has lowest CoF than any vegetable oil, TMP ester or commercial lubricant. Similarly, the WSD was lowest among all the vegetable oil based lubricants and was at par with SAE $20 \mathrm{~W}-50$ and SAE 40 commercial lubricants. FTP was better compared to any vegetable oil or TMP ester. Finally, the energy efficiency of KOTMPE was better than that of other vegetable oils, TMP esters and mineral lubricants. The synthesized ester demonstrated the outstanding performance in terms of friction and wear characteristics along with high thermal stability and energy efficiency worthy of comparison with multiple lubricating products reported by different research groups in available literature during last two decades.
\end{abstract}

Keywords Karanja oil · Biolubricant · Four-ball tester · Transesterification · Tribology

\section{Introduction}

One-third of fuel energy in a typical passenger car and heavy duty vehicle is utilized in overcoming friction. These frictional losses emerge from the crankshaft, piston assembly, valve train, auxiliary components, and tires and brakes of vehicles. Holmberg et al. reported that only $21.5 \%$ and $34 \%$ of total fuel energy is used to run the car and heavy duty vehicle, respectively. The reduction in friction losses might bring about three-fold improvement in fuel economy for both classes of vehicles [1,2]. This can be made possible by use of state of the art high efficiency engines in vehicles and further by reducing frictional losses in engines by applying alternate low viscosity and low shear lubricants [3].
Lubrication is a complex process in which a substance called lubricant is applied between two or more interacting surfaces that are in relative motion to each other [4]. The primary function of a lubricant is to maintain a thin layer of lubrication between these interacting surfaces so as to prevent their direct contact and thus suppress the friction and wear between them. This lubricating function is largely relying on fluid viscosity and therefore makes it the major parameter for selection and application of a lubricant [5]. The viscosity of a lubricant should be high enough to maintain a thick film between the moving components even at extreme temperature and pressure conditions and simultaneously low enough to retain the fluidity of the lubricant around each engine component part [6]. But the viscosity alone is not sufficient to figure out the all round performance

Umesh Chandra Sharma, uc_sharma@hotmail.com | 'Department of Chemical Engineering, UIET, CSJM University, Kanpur 208024, India. ${ }^{2}$ Department of Chemical Engineering, MNNIT, Allahabad 211004, India.

SN Applied Sciences (2019) 1:668 | https://doi.org/10.1007/s42452-019-0706-y

Received: 23 March 2019 / Accepted: 3 June 2019 / Published online: 5 June 2019 
of a lubricant. Henceforth, the tribology of the lubricant should also be investigated to assess its effectiveness, particularly in field conditions [7]. Tribology is defined as the science and technology of interacting surfaces in relative motion and is usually concerned with study of friction, wear and lubrication [8]. Lubrication is the most efficient method for reducing friction and controlling wear between two interacting surfaces in relative motion.

Vegetable oil-based lubricant formulations are becoming increasingly popular not only because of severe environmental concerns associated with use of conventional mineral oil-based lubricants [9], but also due to excellent lubricating properties of the former ones. Vegetable oilbased lubricants possess numerous desirable properties typically required in a high performance lubricant such as high viscosity index, elevated flash and fire point, low volatility and vapor pressure, and high lubricity leading to good anti-wear and friction reducing character [10]. The environmentally generous properties are accelerated biodegradability, recyclability, and low toxicity [11].

Vegetable oils are mostly triesters of glycerol with various short and long chain fatty acids and are usually referred to as triglycerides. Most vegetable oils are amphiphilic in nature comprising distinctly separated polar and non-polar groups in the same molecule. The amphiphilic nature of vegetable oils makes them effective for use in all three lubrication regimes, namely hydrodynamic, mixed, and boundary [11-13]. Several researchers are working on analysis and improvement of the friction properties of vegetable oils and their derived biolubricants for potential application as automotive lubricants [6, 13-28], metal working fluids [29-32], industrial fluid [33], food grade lubricant [34], chain saw, brake fluid, and transmission oil [35].

Studies have been undertaken to investigate the friction and wear properties of avocado oil [29], Calophyllum inophyllum oil [16], canola (rapeseed) oil [17, 25, 29, 36-38], coconut oil [26], corn oil [29], cotton seed oil [30], jatropha oil [13, 19-24, 31, 39], jojoba oil [12], Lunaria annua oil [40], olive oil [29], palm oil [6, 15, 18, 22, 28, 34, $41]$, peanut oil [25, 29], rice bran oil [14], rubber tree seed oil [10, 32], safflower oil [12, 29], sesame oil [29], soybean oil $[25,29,33,42-44]$, and sunflower oil $[27,43,45,46]$, or their chemically modified derivatives. Friction and wear behaviors of direct fatty acids derived synthetic esters have also been examined for their potential application as alternate lubricants $[4,35,47,48]$. Table 1 reports tribological studies carried out in last two decades by different research groups on variety of natural and/or chemically or thermally modified vegetable oils (doped with additives in few studies for improved performance) and fatty acids based synthetic ester biolubricants.
The work reported here intends to characterize the tribological performance of karanja oil derived triester biolubricant for automotive application. Karanja oil is selected as feedstock for biolubricant synthesis as it is non-edible for human and animal consumption due to presence of certain toxic compounds and it can be grown on most soil types under harsh climatic conditions without much care. Such studies are necessary to assess the lubricity of synthesized biolubricant prior to its introduction as a quality product.

\section{Experiment}

In our previous work, as a first step karanja oil methyl ester (KOME) was synthesized from feedstock by two-stage esterification/transesterification process (acid-catalyzed esterification followed by base-catalyzed transesterification). In second step karanja oil trimethylolpropane ester (KOTMPE) biolubricant was synthesized by transesterification of KOME with trimethylolpropane (TMP) under acid catalyst. The viscous flow behavior of KOTMPE was analyzed at high temperature and high shear rate conditions appearing commonly in automotive engines and multitudes of industrial operations [5]. Further the Arrhenius equation and the Ostwald-deWaele power law model were applied to these data for flow characterization [49]. The thermal stability was analyzed by thermogravimetric analysis (TGA) whereas the oxidation stability was determined by Rancimat test [50]. The present work is in continuation of our previous works. Here the friction and wear characteristics of KOTMPE biolubricant are analyzed using Ducom TR30L four-ball tester at rotational speed of 1200 rev $\mathrm{min}^{-1}$ and $75^{\circ} \mathrm{C}$ temperature over $60 \mathrm{~min}$ test duration under normal loads of $15 \mathrm{~kg}$ and $40 \mathrm{~kg}$ as per ASTM D 4172-94 A and B method. Tests are run in duplicate and the average values are reported.

\subsection{Four-ball test machine}

Four-ball tribotester is essential equipment in lubricant research and industry to study tribological properties of lubricating oils and greases [13]. Figure 1 shows the schematic diagram of the equipment. The main components of the equipment are ball pot cum oil cup, lock ring, collet, rotating spindle, heating plate, thermocouple, and torque arm [41]. The equipment uses four identical steel balls: three at the bottom and the fourth on the top. The bottom balls are held together in stationary condition in ball pot cum oil cup with the help of lock ring and the top ball is clamped above them with collet connected at the lower end of vertical spindle of constant speed electric motor. The bottom balls make 
Table 1 Tribological studies on different natural and synthetic biolubricants

\begin{tabular}{|c|c|c|c|}
\hline Test fluid & Equipment & Test conditions & Reference \\
\hline Epoxidized rapeseed oil & Four-ball tribotester & $40 \mathrm{~kg}, 30 \mathrm{~min}, 1450 \pm 50 \mathrm{rpm}$ & [36] \\
\hline Coconut oil & Four-ball tribotester & $40 \mathrm{~kg}, 60 \mathrm{~min}, 75^{\circ} \mathrm{C}, 1200 \mathrm{rpm}$ & [26] \\
\hline Soybean oil derivatives & Four-ball tribotester & $40 \mathrm{~kg}, 15 \mathrm{~min}, 22^{\circ} \mathrm{C}, 1200 \mathrm{rpm}$ & [44] \\
\hline Oleic acid based triester & Four-ball tribotester & $40 \mathrm{daN}, 60 \mathrm{~min}, 1200 \mathrm{rpm}$ & [48] \\
\hline Chemically modified rapeseed oil & Four-ball tribotester & $40 \mathrm{~kg}, 60 \mathrm{~min}, 75^{\circ} \mathrm{C}, 1200 \mathrm{rpm}$ & [17] \\
\hline Oleic acid-based triester & Four-ball tribotester & $40 \mathrm{daN}, 60 \mathrm{~min}, 1200 \mathrm{rpm}$ & {$[35]$} \\
\hline RBD palm olein oil & Four-ball tribotester & $30-60 \mathrm{~kg}, 60 \mathrm{~min}, 75^{\circ} \mathrm{C}, 1200 \mathrm{rpm}$ & [41] \\
\hline Palm oil & Four-ball tribotester & $40 \mathrm{~kg}, 10 \mathrm{~min}, 40^{\circ} \mathrm{C}, 100 \mathrm{rpm}$ & {$[28]$} \\
\hline Palm oil-based TMP ester & Four-ball tribotester & $40 \mathrm{~kg}, 60 \mathrm{~min}, 75 \pm 2^{\circ} \mathrm{C}, 1200 \mathrm{rpm}$ & [6] \\
\hline $\begin{array}{l}\text { Palm oil-based TMP ester with } \mathrm{TiO}_{2} \text { nano- } \\
\text { particles }\end{array}$ & Four-ball tribotester & $\begin{array}{l}40-160 \mathrm{~kg}, 10 \mathrm{~min} \text {, room temperature, } \\
1200 \mathrm{rpm}\end{array}$ & [18] \\
\hline Ricinoleic acid-based tetraesters & Four-ball tribotester & $40 \mathrm{~kg}, 15 \mathrm{~min}, 22^{\circ} \mathrm{C}, 1200 \mathrm{rpm}$ & [4] \\
\hline Calophyllum inophyllum based TMP ester & Four-ball tribotester & $40 \mathrm{~kg}, 60 \mathrm{~min}, 50-100^{\circ} \mathrm{C}, 1200 \mathrm{rpm}$ & [16] \\
\hline Jatropha oil-based TMP ester & Four-ball tribotester & $40 \mathrm{~kg}, 60 \mathrm{~min}, 75^{\circ} \mathrm{C}, 1200 \mathrm{rpm}$ & [31] \\
\hline Rice bran oil & Four-ball tribotester & $2574 \mathrm{MPa}, 60 \mathrm{~min}, 75^{\circ} \mathrm{C}, 1200 \mathrm{rpm}$ & [14] \\
\hline Rubber tree seed oil & Four-ball tribotester & $40 \mathrm{~kg}, 60 \mathrm{~min}, 75^{\circ} \mathrm{C}, 1200 \mathrm{rpm}$ & [10] \\
\hline Ricinoleic acid diesters & Four-ball tribotester & $40 \mathrm{daN}, 60 \mathrm{~min}, 1200 \mathrm{rpm}$ & [47] \\
\hline Jatropha oil blended with SAE 40 & Four-ball tribotester & $80 \mathrm{~kg}, 10 \mathrm{~s}, 27 \pm 7^{\circ} \mathrm{C}, 1200 \mathrm{rpm}$ & {$[21]$} \\
\hline Sunflower oil blended with DLC coating & Four-ball tribotester & $40 \mathrm{~kg}, 60 \mathrm{~min}, 75-100^{\circ} \mathrm{C}, 1200 \mathrm{rpm}$ & {$[27]$} \\
\hline Jatropha oil blended with SAE 40 & Four-ball tribotester & 15 and $40 \mathrm{~kg}, 60 \mathrm{~min}, 75^{\circ} \mathrm{C}, 1500 \mathrm{rpm}$ & {$[20]$} \\
\hline Jatropha oil blended with DLC coating & Four-ball tribotester & $40 \mathrm{~kg}, 60 \mathrm{~min}, 100^{\circ} \mathrm{C}, 1200 \mathrm{rpm}$ & [13] \\
\hline Jatropha oil-based TMP ester & Four-ball tribotester & $40 \mathrm{~kg}, 60 \mathrm{~min}$, room temperature, $1200 \mathrm{rpm}$ & [19] \\
\hline Lunaria annua seed oil-based TMP ester & Four-ball tribotester & $40 \mathrm{~kg}, 60 \mathrm{~min}, 100^{\circ} \mathrm{C}, 1200 \mathrm{rpm}$ & [40] \\
\hline Palm oil-based PE ester & Four-ball tribotester & $40 \mathrm{~kg}, 30 \mathrm{~min}, 50-100^{\circ} \mathrm{C}, 1200 \mathrm{rpm}$ & [34] \\
\hline Palm oil-based PE and TMP ester & Four-ball tribotester & $40 \mathrm{~kg}, 60 \mathrm{~min}$, room temperature, $1200 \mathrm{rpm}$ & {$[15]$} \\
\hline Epoxidized soybean oil & Ball-on-disc tribotester & $181.44 \mathrm{~kg}, 25^{\circ} \mathrm{C}, 5 \mathrm{rpm}$ & [42] \\
\hline $\begin{array}{l}\text { Jojoba, safflower, methyl oleate, methyl } \\
\text { palmitate }\end{array}$ & Ball-on-disc tribotester & $181.44 \mathrm{~kg}, 15 \mathrm{~min}, 25 \pm 2^{\circ} \mathrm{C}, 5 \mathrm{rpm}$ & {$[12]$} \\
\hline Sunflower oil & Ball-on-disc tribotester & $\begin{array}{l}33.4 \mathrm{~N}, 150 \mathrm{~min}, 50^{\circ} \mathrm{C}, 100 \mathrm{rpm}, 12 \mathrm{~mm} \\
\text { stroke }\end{array}$ & {$[45]$} \\
\hline Modified soybean oil with additives & Ball-on-disc tribotester & $181.44 \mathrm{~kg}, 15 \mathrm{~min}, 25 \pm 2^{\circ} \mathrm{C}, 5 \mathrm{rpm}$ & [33] \\
\hline Soybean oil derivatives & Ball-on-disc tribotester & $181.44 \mathrm{~kg}, 15 \mathrm{~min}, 25 \pm 2^{\circ} \mathrm{C}, 5 \mathrm{rpm}$ & [44] \\
\hline $\begin{array}{l}\text { Epoxidized soybean and sunflower oils with } \\
\text { zinc oxide and copper oxide nanoparticles }\end{array}$ & High frequency reciprocating rig & $10 \mathrm{~N}, 60 \mathrm{~min}, 50^{\circ} \mathrm{C}, 20 \mathrm{~Hz}, 1 \mathrm{~mm}$ stroke & [43] \\
\hline $\begin{array}{l}\text { Methyl oleate and canola biodiesel derived } \\
\text { TMP triesters }\end{array}$ & High frequency reciprocating rig & $75 \mathrm{~min}, 50 \mathrm{~Hz}$ & [37] \\
\hline Palm oil-based TMP ester & High frequency reciprocating rig & $10 \mathrm{~N}, 60 \mathrm{~min}, 10 \mathrm{~Hz}$ & [6] \\
\hline Lunaria annua seed oil-based TMP ester & High frequency reciprocating rig & $1 \mathrm{~kg}, 60 \mathrm{~min}, 100^{\circ} \mathrm{C}, 50 \mathrm{~Hz}$ & {$[40]$} \\
\hline $\begin{array}{l}\text { Palm and jatropha biodiesel blended with } \\
\text { diesel fuel }\end{array}$ & High frequency reciprocating rig & $\begin{array}{l}160 \mathrm{~N}, 120 \mathrm{~min}, 70^{\circ} \mathrm{C}, 240 \mathrm{rpm}, 84 \mathrm{~mm} \\
\text { stroke }\end{array}$ & {$[22]$} \\
\hline $\begin{array}{l}\text { Canola, peanut, soybean, and chicken fat } \\
\text { biodiesels blended with SAE } 15 \text { W- } 40\end{array}$ & Pin-on-disc tribotester & $19.2 \mathrm{~N}, 1 \mathrm{~h} 51 \mathrm{~min}, 17-19^{\circ} \mathrm{C}$ & {$[25]$} \\
\hline Jatropha oil blended with SAE 40 & Pin-on-disc tribotester & $30 \mathrm{~N}, 60 \mathrm{~min}, 2000 \mathrm{rpm}$ & [23] \\
\hline Jatropha oil blended with SAE 40 & Pin-on-disc tribotester & $30 \mathrm{~N}, 60 \mathrm{~min}, 2000 \mathrm{rpm}$ & {$[21]$} \\
\hline Jatropha oil blended with SAE 40 & Pin-on-disc tribotester & $30 \mathrm{~N}, 60 \mathrm{~min}, 2000 \mathrm{rpm}$ & {$[24]$} \\
\hline Cottonseed and SAE 40 oil & Pin-on-disc tribotester & $10-30 \mathrm{~N}, 300-900 \mathrm{rpm}$ & {$[30]$} \\
\hline $\begin{array}{l}\text { Avocado, canola, corn, olive, peanut, saf- } \\
\text { flower, sesame, and soybean oils }\end{array}$ & Pin-on-disc tribotester & $10 \mathrm{~N}, 23.2 \mathrm{~h}$, ambient temperature, $21.5 \mathrm{rpm}$ & {$[29]$} \\
\hline Canola oil with boron nitride additives & Pin-on-disc tribotester & $\begin{array}{l}10 \mathrm{~N}, 50.5 \mathrm{~min} \text {, ambient temperature, } \\
21.5 \mathrm{rpm}\end{array}$ & {$[38]$} \\
\hline
\end{tabular}


Table 1 (continued)

\begin{tabular}{llll}
\hline Test fluid & Equipment & Test conditions & Reference \\
\hline Rubber seed oil & $\begin{array}{l}\text { Ring compression test on Califor- } \\
\text { nia Bearing Ratio compressing } \\
\text { machine }\end{array}$ & $10 \mathrm{~N}, 30^{\circ} \mathrm{C}$ & {$[32]$} \\
Sunflower oil based oleogels/greases & $\begin{array}{l}\text { Tribology cell } \\
\text { [ }\end{array}$ & $3 \mathrm{~N}, 20 \mathrm{~min}, 25^{\circ} \mathrm{C}, 100 \mathrm{rpm}$ & {$[46]$} \\
\hline
\end{tabular}

three-point contact with the top ball. The stationary bottom balls are immersed in the lubricant being tested and pressed against the top ball. The appropriate load is applied on the balls from the bottom and the top ball is made to rotate at required speed for a fixed length of time $[4,44]$.

\subsection{Ball material}

The balls used in the experiment are made of AISI 52100 chrome steel with following specifications: diameter $12.7 \mathrm{~mm}$, hardness 64-66 HRC, high surface finish grade 25 , density $7.8334 \mathrm{~g} / \mathrm{cm}^{3}$, tensile strength $2241 \mathrm{MPa}$, and yield strength $2034 \mathrm{MPa}$. The chemical composition of AISI 52100 steel is given in Table 2.

\subsection{Test procedure}

Four new identical steel balls were taken in each experiment. The balls and the ball pot cum oil cup were thoroughly cleaned with toluene and then wiped using a fresh lint free industrial wipe until they were completely dry prior to each experiment. $10 \mathrm{ml}$ test lubricant was poured into the oil cup to cover the bottom stationary balls to a depth of at least $3 \mathrm{~mm}$. The ball pot components were then assembled in the four-ball tribotester and the lubricant was heated to the desired temperature. When the desired temperature was achieved, the electric motor was started to drive the top ball at set constant speed and the requisite load was applied gradually to avoid shock loading. At the end of pre-determined test period, the equipment was turned off and the stationary balls were analyzed under scanning electron microscope to measure the wear scar produced. Each test was run in duplicate and the average
Fig. 1 Schematic diagram of four-ball tribotester

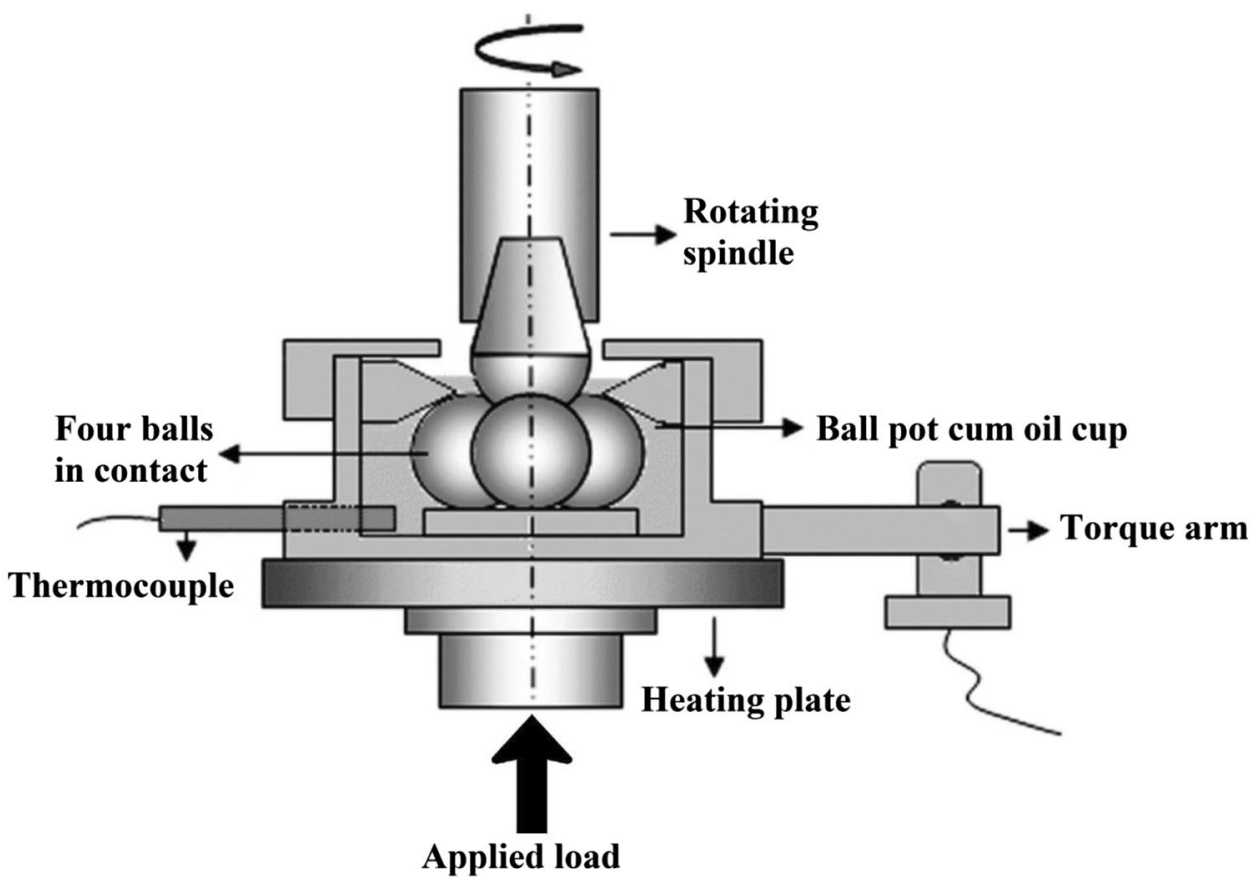

Table 2 Chemical composition of AISI 52100 chrome steel

\begin{tabular}{llllllll}
\hline Element & $\mathrm{C}$ & $\mathrm{Cr}$ & $\mathrm{Si}$ & $\mathrm{Mn}$ & $\mathrm{P}$ & $\mathrm{S}$ & $\mathrm{Fe}$ \\
\hline AISI 52100 steel (\%) & $0.95-1.10$ & $1.30-1.60$ & $0.15-0.30$ & 0.25 (Max) & 0.03 (Max) & 0.025 (Max) & Balance
\end{tabular}


values are reported as WSD $[6,16,20]$. The frictional torque applied on three bottom balls during the course of experiment was measured by the torque arm connected with friction recording device through spring [21].

\subsection{CoF evaluation}

The magnitude of friction between two rubbing bodies or surfaces is expressed by a dimensionless number called the CoF. It is the ratio between the force of friction between two bodies and the normal force pressing those together [16]. CoF plays an important role in determining the transmission efficiency of a lubricated system. Low value of CoF corresponds to low friction between the two rubbing surfaces and hence the transmission efficiency will be higher as less force is required for sliding [19, 34]. The CoF in four-ball experiment is calculated using the following equation $[13,23]$ :

$f=\frac{T \sqrt{ } 6}{3 r W}$

where $f=\operatorname{CoF}$ (dimensionless), $T=$ frictional torque (kg$\mathrm{mm}), r=$ distance from the centre of the contact surface on the lower balls to the axis of rotation $(\mathrm{mm})$, and $W=$ applied load $(\mathrm{kg})$. The value of $r$ is determined to be $3.67 \mathrm{~mm}$ in most studies.

\subsection{Flash temperature parameter}

The concept of flash temperature parameter (FTP) was introduced by T.B. Lane in 1957 to assess the possibility of lubricant breakdown in operation [51]. This parameter has now acquired a status of recognition in engineering operations such as cutting and forming tools and is weighed at the time of lubricant selection for industrial applications. The frictional heat generated in contact area between two rubbing surfaces is responsible for development of localized heat zones that in turn raise the temperature of surrounding lubricant. FTP is a mathematically calculated number that indicates the lowest temperature at which a lubricant can vaporize to form an ignitable mixture with air [52].

Shahabuddin et al. [21], Habibullah et al. [16, 20], Rahman et al. [53], and several other researchers have used following relation to determine FTP. The relation was originally proposed by Lane for four-ball tribotester.

Flash Temperature Parameter (FTP) $=\frac{W}{d^{1.4}}$

where $W=$ applied load $(\mathrm{kg})$ and $d=$ mean WSD $(\mathrm{mm})$ at this applied load.
Equation 2 exhibits inverse relationship between FTP and WSD at constant load [52]. Therefore, a lubricant should have higher FTP for better performance as the lubricant will not evaporate at low temperature and the film thickness will be high to prevent friction and wear; whereas a lubricant with low FTP is more susceptible to undergo film break down at low temperature leading to partial or total loss of lubrication [53].

\subsection{Energy consumption}

Habibullah et al. [16] gave following expression, derived from energy conservation equation, for analysis of energy consumption in a four-ball tribotester.

Thermal energy $(\mathrm{TE})=\frac{f W g r}{1000}$

where $T E=$ thermal energy $(\mathrm{J}), f=\mathrm{CoF}$ (dimensionless), $W=$ applied load $(\mathrm{kg}), g=$ gravitational acceleration $\left(\mathrm{ms}^{-2}\right)$, and $r=$ distance from the centre of the contact surface on the lower balls to the axis of rotation $(\mathrm{mm})$ that is found to be $3.67 \mathrm{~mm}$.

\section{Results}

The average CoF at $15 \mathrm{~kg}$ and $40 \mathrm{~kg}$ loads under test conditions of $75^{\circ} \mathrm{C}$ temperature, $1200 \mathrm{rev} \mathrm{min}{ }^{-1}$ speed and 60 min test duration were computed to be 0.100 and 0.042 , respectively using Eq. 1 from frictional torque data recorded by four-ball tribotester (Fig. 2a and b). The mean WSDs at two loads were observed to be $0.30 \mathrm{~mm}$ and $0.44 \mathrm{~mm}$ (Fig. 3a and b), respectively. FTPs at two loads were evaluated using Eq. 2 as 80.932 and 126.249 , respectively. Similarly, the energy consumption was evaluated in terms of thermal energy using Eq. 3 and the values were $0.054 \mathrm{~J}$ and $0.060 \mathrm{~J}$, respectively.

\section{Discussion}

Table 3 presents the average CoF and WSD data for several vegetable oils, TMP esters, and commercial lubricants with their respective test conditions as reported by different research groups. FTP and TE data were calculated by this author. Test results of present study have also been included for the purpose of comparison.

\subsection{CoF analysis}

According to Aravind et al. [10], the CoF values for vegetable oils range from 0.06 to 0.09 and according to Habibullah et al. [16], the CoF values for lubricants range from 

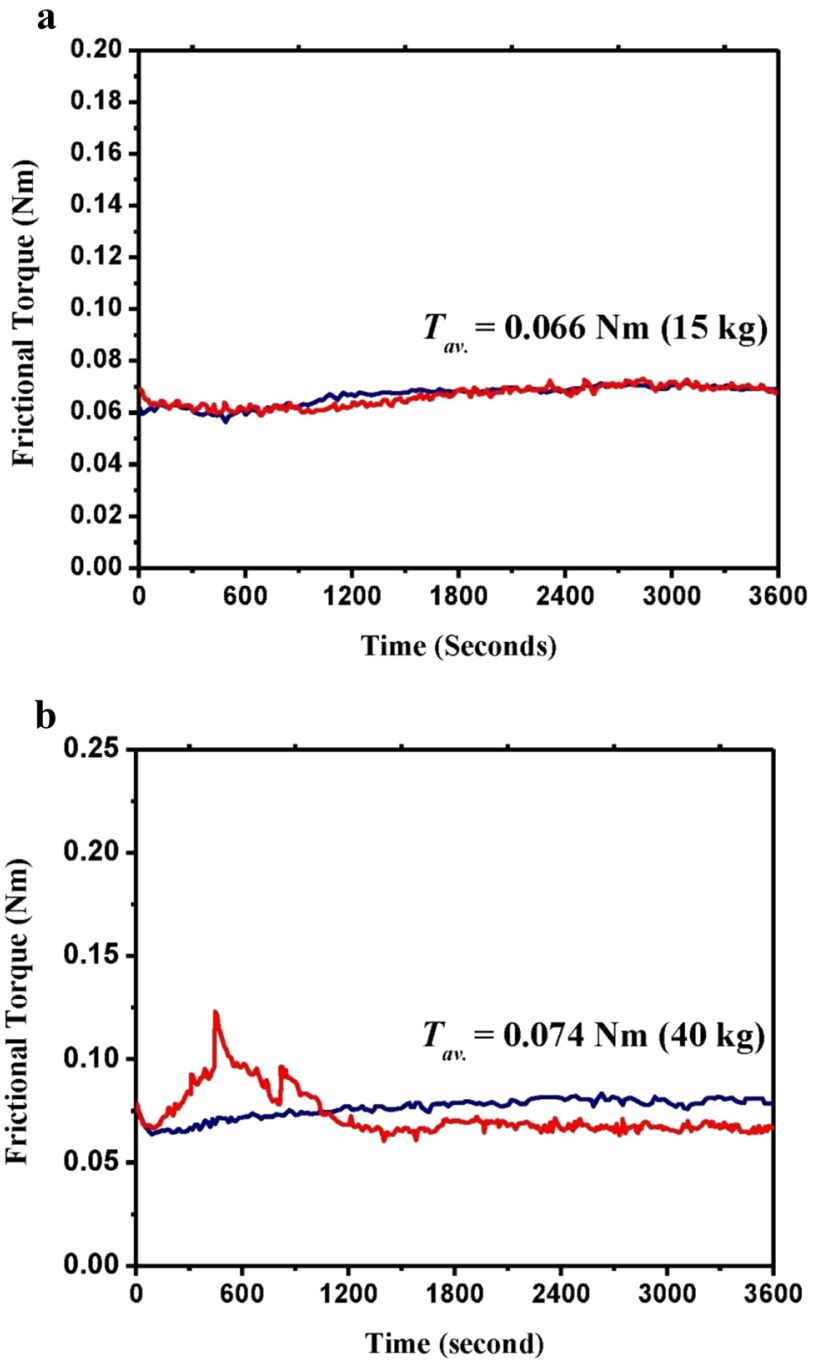

Fig. 2 a Frictional torque for KOTMPE biolubricant at $15 \mathrm{~kg}$ load under test conditions of $75{ }^{\circ} \mathrm{C}$ temperature and $1200 \mathrm{rev} \mathrm{min}{ }^{-1}$ speed, b Frictional torque for KOTMPE biolubricant at $40 \mathrm{~kg}$ load under test conditions of $75{ }^{\circ} \mathrm{C}$ temperature and $1200 \mathrm{rev} \mathrm{min}{ }^{-1}$ speed

0.05 to 0.14 for wide automotive applications. In present study, the CoF for synthesized KOTMPE at $40 \mathrm{~kg}$ load is lowest among all the lubricants tested and even less than the lower limit mentioned in available literature. The low CoF for KOTMPE shows that the lubricant film formed at the rubbing surface is exceptionally effective with high lubricity at high temperature. The test results are quite in agreement with high viscosity index of 206 for KOTMPE lubricant base oil.

\subsection{Wear scar diameter analysis}

Aravind et al. [10] mentioned the WSD range for commodity oils as $0.51-0.87 \mathrm{~mm}$. WSD data in Table 3 show that the synthesized KOTMPE has the lowest WSDs among all
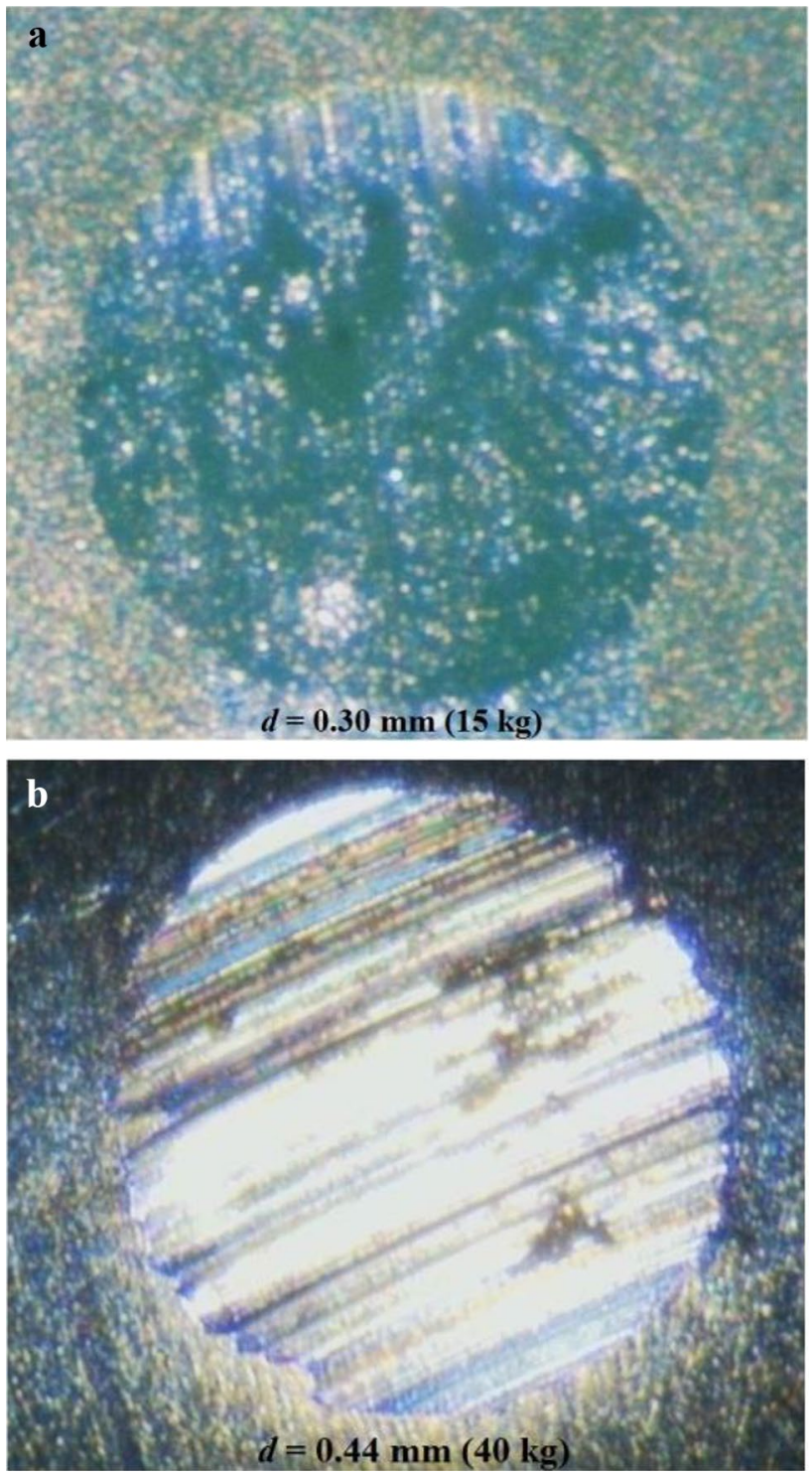

Fig. 3 a Wear scar diameter for KOTMPE biolubricant at $15 \mathrm{~kg} \mathrm{load}$ under test conditions of $75{ }^{\circ} \mathrm{C}$ temperature and $1200 \mathrm{rev} \mathrm{min}^{-1}$ speed, b Wear scar diameter for KOTMPE biolubricant at $40 \mathrm{~kg}$ load under test conditions of $75{ }^{\circ} \mathrm{C}$ temperature and $1200 \mathrm{rev} \mathrm{min}^{-1}$ speed

the vegetable oils and their derived biolubricants and the values are comparable to that of commercial mineral lubricants SAE $20 \mathrm{~W}-50$ and SAE 40 . The low WSD for KOTMPE indicates presence of a stable lubricant film between the interacting surfaces even at higher loads.

The low anti-friction (CoF) and anti-wear (WSD) performance of KOTMPE is largely attributed to ester and fatty acid components of biolubricant. The ester groups represent the polar segment of vegetable oil based lubricants, whereas the fatty acid chains with varying length, degree of unsaturation, and stereochemistry represent the non-polar segment [12]. The

\section{SN Applied Sciences}


Table 3 Average CoF and WSD, and calculated FTP and TE values for several vegetable oils, biolubricants, and commercial lubricants

\begin{tabular}{|c|c|c|c|c|c|c|}
\hline Sample & $\mathrm{CoF}$ & WSD (mm) & FTP & $\operatorname{TE}(J)$ & Test parameter & Reference \\
\hline \multirow[t]{3}{*}{ Coconut oil } & 0.070 & 0.540 & 94.778 & 0.101 & $40 \mathrm{~kg}, 60 \mathrm{~min}, 75^{\circ} \mathrm{C}, 1200 \mathrm{rpm}$ & {$[26]$} \\
\hline & 0.092 & 0.797 & 54.956 & 0.133 & $40 \mathrm{~kg}, 60 \mathrm{~min}, 75^{\circ} \mathrm{C}, 1200 \mathrm{rpm}$ & {$[10]$} \\
\hline & 0.101 & 0.601 & 81.589 & 0.146 & $40 \mathrm{~kg}, 60 \mathrm{~min}, 75^{\circ} \mathrm{C}, 1200 \mathrm{rpm}$ & {$[14]$} \\
\hline Lesquerella & 0.045 & 0.857 & 49.646 & 0.065 & $40 \mathrm{~kg}, 60 \mathrm{~min}, 75^{\circ} \mathrm{C}, 1200 \mathrm{rpm}$ & {$[54]$} \\
\hline Pennycress & 0.054 & 0.769 & 57.778 & 0.078 & $40 \mathrm{~kg}, 60 \mathrm{~min}, 75^{\circ} \mathrm{C}, 1200 \mathrm{rpm}$ & {$[54]$} \\
\hline \multirow[t]{2}{*}{ Rapeseed oil } & 0.078 & 0.630 & 76.381 & 0.112 & $40 \mathrm{~kg}, 60 \mathrm{~min}, 75^{\circ} \mathrm{C}, 1450 \pm 50 \mathrm{rpm}$ & {$[36]$} \\
\hline & 0.090 & 0.660 & 71.565 & 0.130 & $40 \mathrm{~kg}, 60 \mathrm{~min}, 75^{\circ} \mathrm{C}, 1200 \mathrm{rpm}$ & [17] \\
\hline Rice bran oil & 0.073 & 0.585 & 84.731 & 0.105 & $40 \mathrm{~kg}, 60 \mathrm{~min}, 75^{\circ} \mathrm{C}, 1200 \mathrm{rpm}$ & {$[14]$} \\
\hline Rubber seed oil & 0.089 & 0.690 & 67.247 & 0.128 & $40 \mathrm{~kg}, 60 \mathrm{~min}, 75^{\circ} \mathrm{C}, 1200 \mathrm{rpm}$ & {$[10]$} \\
\hline RBD palm olein oil & 0.068 & 0.828 & 52.098 & 0.098 & $40 \mathrm{~kg}, 60 \mathrm{~min}, 75^{\circ} \mathrm{C}, 1200 \mathrm{rpm}$ & {$[41]$} \\
\hline \multirow[t]{2}{*}{ Sunflower oil } & 0.060 & 0.616 & 78.822 & 0.086 & $40 \mathrm{~kg}, 60 \mathrm{~min}, 75^{\circ} \mathrm{C}, 1200 \mathrm{rpm}$ & [14] \\
\hline & 0.078 & 0.882 & 47.687 & 0.112 & $40 \mathrm{~kg}, 60 \mathrm{~min}, 75^{\circ} \mathrm{C}, 1200 \mathrm{rpm}$ & {$[10]$} \\
\hline Waste cooking oil & 0.065 & 0.610 & 79.909 & 0.094 & $40 \mathrm{~kg}, 60 \mathrm{~min}, 75^{\circ} \mathrm{C}, 1200 \mathrm{rpm}$ & {$[55]$} \\
\hline CITMP ester & 0.075 & 0.895 & 46.721 & 0.108 & $40 \mathrm{~kg}, 60 \mathrm{~min}, 70^{\circ} \mathrm{C}, 1200 \mathrm{rpm}$ & {$[16]$} \\
\hline Jatropha TMP ester & 0.060 & 0.565 & 88.959 & 0.086 & $40 \mathrm{~kg}, 60 \mathrm{~min}$, room temp, $1200 \mathrm{rpm}$ & [19] \\
\hline \multirow[t]{2}{*}{ Karanja TMP ester } & 0.100 & 0.300 & 80.932 & 0.054 & $15 \mathrm{~kg}, 60 \mathrm{~min}, 75^{\circ} \mathrm{C}, 1200 \mathrm{rpm}$ & Present study \\
\hline & 0.042 & 0.440 & 126.249 & 0.060 & $40 \mathrm{~kg}, 60 \mathrm{~min}, 75^{\circ} \mathrm{C}, 1200 \mathrm{rpm}$ & Present study \\
\hline Lunaria Ann. TMP ester & 0.080 & 0.530 & 97.291 & 0.115 & $40 \mathrm{~kg}, 60 \mathrm{~min}, 100^{\circ} \mathrm{C}, 1200 \mathrm{rpm}$ & [40] \\
\hline Palm TMP ester & 0.078 & 0.777 & 56.947 & 0.112 & $40 \mathrm{~kg}, 60 \mathrm{~min}, 75 \pm 2^{\circ} \mathrm{C}, 1200 \mathrm{rpm}$ & {$[6]$} \\
\hline Epoxy rapeseed oil & 0.055 & 0.710 & 64.610 & 0.079 & $40 \mathrm{~kg}, 60 \mathrm{~min}, 75^{\circ} \mathrm{C}, 1450 \pm 50 \mathrm{rpm}$ & [36] \\
\hline \multirow[t]{2}{*}{ SAE $20 \mathrm{~W}-40$} & 0.106 & 0.575 & 86.801 & 0.153 & $40 \mathrm{~kg}, 60 \mathrm{~min}, 75^{\circ} \mathrm{C}, 1200 \mathrm{rpm}$ & {$[10]$} \\
\hline & 0.117 & 0.549 & 92.610 & 0.168 & $40 \mathrm{~kg}, 60 \mathrm{~min}, 75^{\circ} \mathrm{C}, 1200 \mathrm{rpm}$ & [14] \\
\hline SAE 20W-50 & 0.080 & 0.360 & 167.200 & 0.115 & $40 \mathrm{~kg}, 60 \mathrm{~min}, 75^{\circ} \mathrm{C}, 1200 \mathrm{rpm}$ & {$[26]$} \\
\hline SAE 40 & 0.068 & 0.491 & 216.559 & 0.196 & $80 \mathrm{~kg}, 10 \mathrm{~s}, 27 \pm 7^{\circ} \mathrm{C}, 1200 \mathrm{rpm}$ & {$[21]$} \\
\hline
\end{tabular}

lubricant molecules orient themselves with the polar ester end adsorbed strongly onto the metal surface and the non-polar fatty acid end extended away from the metal surface. The ester groups principally strengthen the binding of the molecules increasing the strength of the lubricant film and thus provide strong resistance to shear forces $[6,19]$. The fatty acid components make closely packed mono- or multi-molecular surface layers that prevent the direct metal-to-metal contact and progression of pits and spalling on the metal surfaces $[4,34,44]$.

In general, the WSD increases with increase in normal load. As the normal load is increased, the two rolling surfaces move closer to each other due to high surface pressure and thus lead to increased WSD $[20,41]$. Temperature has same effect on WSD as normal load. With increase in temperature, the viscosity of the lubricant decreases thinning the lubricant film between the two surfaces. The two surfaces come closer as under effect of high load and the WSD increases. Under conditions of excessive load or temperature, the lubricant film may completely wear out leading to welding of two surfaces.

\subsection{Flash temperature parameter analysis}

The FTP measurements for synthesized KOTMPE at 15 and $40 \mathrm{~kg}$ loads followed the general trend of increase in FTP with increase in load [20]. The FTP of test sample at $40 \mathrm{~kg}$ load is substantially higher than other vegetable oils and their derived biolubricants, and is only smaller than commercial mineral lubricants. The high FTP for KOTMPE corresponds to increased possibility of synthesized lubricant film sustaining at higher temperatures without being destroyed between the two surfaces in relative motion.

FTP signifies the critical temperature below which the lubricant film between two rubbing surfaces can perform without thermal breakdown [16]. Equation 2 shows the dependence of FTP on applied load and WSD. In general, when the applied load is increased, the FTP is increased [20]. In case, the applied load is constant, FTP is higher for lower WSD and lower for higher WSD [21]. Regarding dependence on temperature, the FTP decreases with increase in temperature due to degradation of lubricant at high temperature [16]. 


\subsection{Energy consumption analysis}

The synthesized KOTMPE affords the lowest energy consumption as compared to other lubricants analyzed under similar test conditions. Studies reveal that lubricant temperature does have a primary effect on energy consumption because the viscosity of the lubricant decreases with increase in temperature making it easier for lubricant to flow and form a film between the rolling surfaces. This results in reduced energy consumption [16].

\subsection{Biolubricant composition and lubricating properties}

The lubricating properties of vegetable oils are considerably governed by their chemical composition. For instance, a triglyceride molecule with small unsaturation has better oxidative stability than a molecule having significant unsaturation [12]. The fatty acid carbon chain regulates the friction and wear properties of vegetable oils. The long carbon chain provides high strength to lubrication film and low frictional properties. As the acid value and iodine value of vegetable oil increases, the coefficient of friction (CoF) decreases and wear increases. This behavior can be explained in the following manner. The acid value of the oil expresses the free fatty acid content in the sample, whereas the iodine value indicates the degree of unsaturation of the constituent fatty glycerides. The increased acid value thus signifies more free fatty acids causing CoF to reduce. With increase in iodine value, the unsaturation as well as the free fatty acid forming capacity of oil increases and thus the $\mathrm{CoF}$ reduces. As the unsaturation increases, the free fatty acid content in oil increases, but the oxidative stability of oil and wear of metal surfaces decreases. The high wear of vegetable oils is believed to be due to the chemical wear initiated by the presence of high free fatty acids. The high saponification value of certain vegetable oils and formation of peroxides at high temperature also contribute significantly to high wear [14]. Here in this experiment the acid value of KO after two-stage esterification/transesterification process was reduced to 1.64 from $11.52 \mathrm{mg} \mathrm{KOH} / \mathrm{g}$ (KOME synthesis) and further to $1.04 \mathrm{mg} \mathrm{KOH} / \mathrm{g}$ after transesterification process (KOTMPE synthesis).

The tribological performance of KOTMPE biolubricant base oil is not a stand-alone property and is associated fairly with viscous flow and thermal stability behaviors of test sample discussed elsewhere $[5,50]$ by this research group. Results of these previous studies are reproduced here to carry this discussion further.

The viscous flow behavior of KOTMPE was first analyzed at constant shear rates of 10,100 and $1000 \mathrm{~s}^{-1}$ in temperature range of $10-70^{\circ} \mathrm{C}$. In general, the viscosity was found to decease with increase in temperature. The viscosity first decreased sharply between 10 and $20^{\circ} \mathrm{C}$ followed by smaller decrease between 20 to $60^{\circ} \mathrm{C}$. Thereafter there was a small increase in viscosity after $60^{\circ} \mathrm{C}$ due to gelation. This gain in viscosity was more evident at low shear rates as compared to high shear rates simply because of smaller torque applied on KOTMPE at low shear rate. Next, the flow behavior was analyzed at constant temperatures of 27,60 and $90^{\circ} \mathrm{C}$ under shear rates varying between 100 to $1000 \mathrm{~s}^{-1}$. The viscosity was found to increase with increase in shear rate at given temperature. KOTMPE biolubricant displayed shear rate thickening behavior which is a desirable property for lubricants intended for high temperature and high shear rate applications. Such lubricants will maintain their viscosity and subsequently the required lubricity between rolling engine components at high temperature and high shear rate. Further, the shear stress versus shear rate behavior was studied at 10,25 and $50^{\circ} \mathrm{C}$ temperatures. The KOTMPE demonstrated Newtonian fluid behavior at selected experimental temperatures. The study proved the ability of synthesized KOTMPE biolubricant base oil in sustaining its viscosity at high temperatures [5].

TGA thermogram of KOTMPE in inert nitrogen atmosphere shown in Fig. 4 produced $1 \%$ weight loss in sample at $180.36^{\circ} \mathrm{C}, 50 \%$ weight loss at $312.53^{\circ} \mathrm{C}$ and $90 \%$ weight loss at $451.11^{\circ} \mathrm{C}$. The onset and offset decomposition temperatures were obtained at $248{ }^{\circ} \mathrm{C}$ and $470^{\circ} \mathrm{C}$, respectively. The maximum decomposition temperature appeared at $445.73{ }^{\circ} \mathrm{C}$ with $0.07448 \mathrm{mg}$ weight loss. The temperature plateau initiating at $485.69^{\circ} \mathrm{C}$ displayed no further considerable weight loss.

The high thermal efficiency of KOTMPE is accredited to formation of ester groups at sites of unsaturation in fatty acid chains through successive chemical modifications as asserted by the Fourier-transform infrared (FTIR) spectroscopy. The FTIR spectrums of feedstock KO, intermediate KOME biodiesel and the final KOTMPE biolubricant base oil are shown in Fig. 5. The peaks at wavelengths 3473 and $3464 \mathrm{~cm}^{-1}$ in KO and KOME spectrums, respectively, correspond to alcohol group $(-\mathrm{OH})\left(3500-3100 \mathrm{~cm}^{-1}\right)$ stretching. The absence of $-\mathrm{OH}$ group in KOTMPE spectrum confirmed the successful realization of esterification reaction. The peaks at wavelength $3006 \mathrm{~cm}^{-1}$ correspond to aliphatic $\mathrm{C}=\mathrm{C}$ double bond bending vibration, while the peaks at wavelengths $2925-2854 \mathrm{~cm}^{-1}$ represent the stretching vibration of aliphatic $\mathrm{CH}_{2}$ and $\mathrm{CH}_{3}$ in three specimens. The peaks at wavelengths $1746-1743 \mathrm{~cm}^{-1}$ mark the stretching vibration of ester carbonyl $(\mathrm{C}=\mathrm{O})$ in specimens. The total disappearance of $\mathrm{C}=\mathrm{C}$ double bonds at wavelength $1604 \mathrm{~cm}^{-1}$ in $\mathrm{KO}$ and appearance of $\mathrm{C}-\mathrm{O}-\mathrm{C}$ bands in KOME and KOTMPE at 852 and $822 \mathrm{~cm}^{-1}$, respectively, pointed out the conversion of most of double bonds in feedstock. The peaks at wavelengths 1196 and $1201 \mathrm{~cm}^{-1}$ 
Fig. 4 TGA/DSC thermogram of KOTMPE biolubricant in inert nitrogen atmosphere

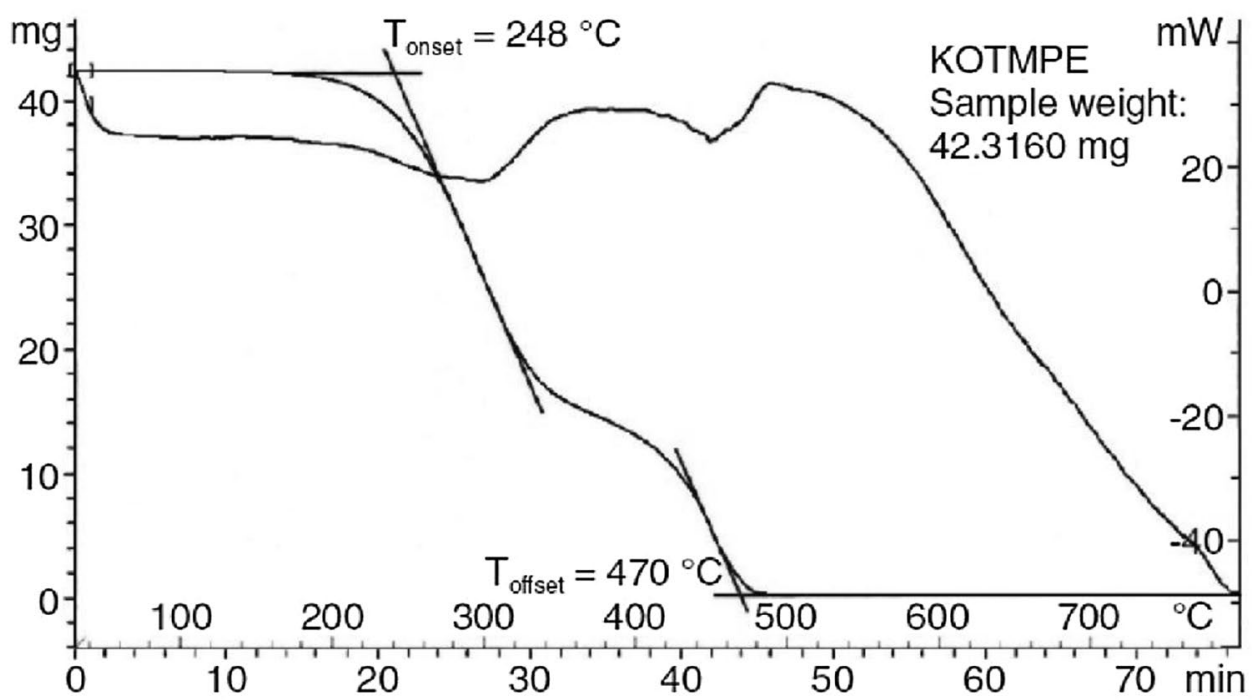

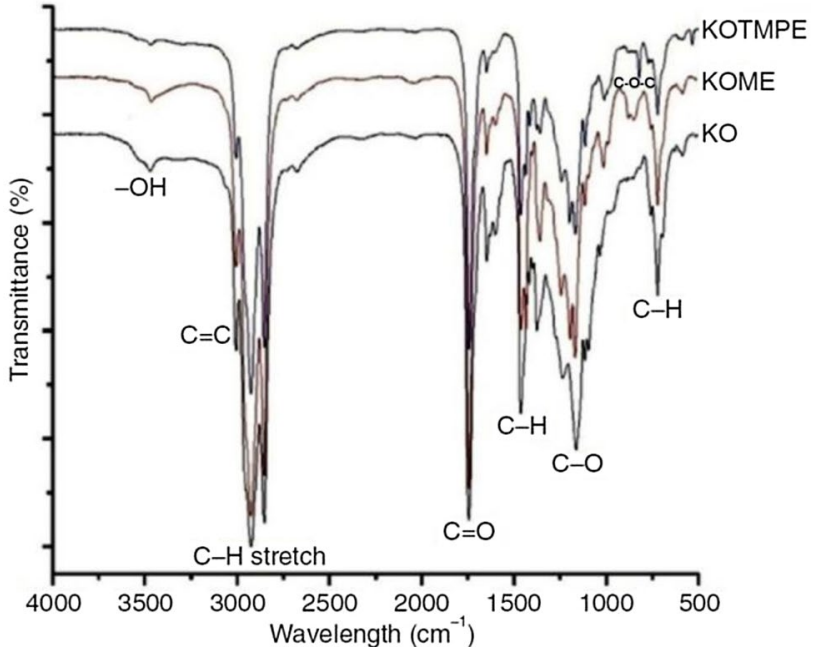

Fig. 5 FTIR spectrums of KO, KOME and KOTMPE specimens

in KOME and KOTMPE spectrums, respectively, specified the presence of $\mathrm{C}-\mathrm{O}$ bond as an outcome of ester formation. The peaks at 1118 and $1116 \mathrm{~cm}^{-1}$ in $\mathrm{KO}, \mathrm{KOME}$, and KOTMPE spectrums are assigned to $\mathrm{C}-\mathrm{O}$ stretching ester. The three spectrums further exhibited absorption bands at $723 \mathrm{~cm}^{-1}$ distinctive of aliphatic $\mathrm{C}-\mathrm{H}$ group vibration [50].

\section{Conclusion}

The tribological behavior of KOTMPE was investigated in this study. The following conclusions can be drawn on the basis of the experimental study and the obtained results:

- KOTMPE has the lowest CoF compared to any other vegetable oil, TMP ester or commercial mineral lubri- cant under test conditions of $40 \mathrm{~kg}$ load, $75^{\circ} \mathrm{C}$ temperature, 1200 rev $\mathrm{min}^{-1}$ speed and $60 \mathrm{~min}$ test duration. The CoF data at $15 \mathrm{~kg}$ load for other vegetable oils, TMP esters and commercial mineral lubricants are not available for comparison.

- KOTMPE has the lowest WSD among all the vegetable oil based lubricants considered in this study. Its performance is even much better than SAE 20W-40 commercial mineral lubricant and is at level with SAE 20W-50 and SAE 40 lubricants.

- The low CoF and WSD for KOTMPE is due to combined effect of increase in number of polar ester functional groups (triester) in the oil structure through chemical modification and dense fatty acid layer caused by high percentage of oleic acid in karanja oil.

- KOTMPE has FTP higher than vegetable oils, other TMP esters and SAE 20W-40 commercial mineral lubricant, however, it is lower than SAE 20W-50 and SAE 40 commercial lubricants.

- KOTMPE has excellent performance in terms of lowest energy consumption compared to any vegetable oil, TMP ester or commercial mineral lubricant under similar test conditions.

Results of this experimental study are quite encouraging for favorable applications of synthesized karanja oil TMP ester on account of its excellent performance in terms of friction and wear characteristics along with high thermal stability and energy efficiency.

\section{Compliance with ethical standards}

Conflict of interest On behalf of both the authors, the corresponding author states that there is no conflict of interest. 


\section{References}

1. Holmberg K, Andersson P, Erdemir A (2012) Global energy consumption due to friction in passenger cars. Tribol Int 47:221-234. https://doi.org/10.1016/j.triboint.2011.11.022

2. Holmberg K, Andersson P, Nylund NO, Mäkelä K, Erdemir A (2014) Global energy consumption due to friction in trucks and buses. Tribol Int 78:94-114. https://doi.org/10.1016/j.tribo int.2014.05.004

3. Hamdan SH, Chong WWF, Ng JH, Ghazali MJ, Wood RJK (2017) Influence of fatty acid methyl ester composition on tribological properties of vegetable oils and duck fat derived biodiesel. Tribol Int 113:76-82. https://doi.org/10.1016/j.tribo int.2016.12.008

4. Salih N, Salimon J, Yousif E, Abdullah BM (2013) Biolubricant basestocks from chemically modified plant oils: ricinoleic acid based-tetraesters. Chem Cent J 7:128. https://doi. org/10.1186/1752-153X-7-128

5. Sharma UC, Sachan S, Trivedi RK (2018) Viscous flow behaviour of karanja oil based bio-lubricant base oil. J Oleo Sci 67(1):105-111. https://doi.org/10.5650/jos.ess 17140

6. Zulkifli NWM, Kalam MA, Masjuki HH, Shahabuddin M, Yunus R (2013) Wear prevention characteristics of a palm oil-based TMP (trimethylolpropane) ester as an engine lubricant. Energy 54:167-173. https://doi.org/10.1016/j.energy.2013.01.038

7. Bart JCJ, Gucciardi E, Cavallaro S (2013) Biolubricants science and technology. Woodhead, Cambridge

8. Czichos H (1978) Tribology. Elsevier, Amsterdam

9. Mobarak HM, Masjuki HH, Niza Mohamad E, Kalam MA, Rashedul HK, Rashed MM, Habibullah M (2014) Tribological properties of amorphous hydrogenated $(\mathrm{a}-\mathrm{C}: \mathrm{H})$ and hydrogen-free tetrahedral (ta-C) diamond-like carbon coatings under jatropha biodegradable lubricating oil at different temperatures. Appl Surf Sci 317:581-592. https://doi.org/10.1016/j.apsusc.2014.08.168

10. Aravind A, Joy ML, Nair KP (2015) Lubricant properties of biodegradable rubber tree seed (Hevea brasiliensis Muell. Arg) oil. Ind Crop Prod 74:14-19. https://doi.org/10.1016/j.indcr op.2015.04.014

11. Quinchia LA, Delgado MA, Reddyhoff T, Gallegos C, Spikes HA (2014) Tribological studies of potential vegetable oil-based lubricants containing environmentally friendly viscosity modifiers. Tribol Int 69:110-117. https://doi.org/10.1016/j.tribo int.2013.08.016

12. Biresaw G, Adhvaryu A, Erhan SZ (2003) Friction properties of vegetable oils. J Am Oil Chem Soc 80(7):697-704. https://doi. org/10.1007/s11746-003-0760-7

13. Mobarak HM, Masjuki HH, Niza Mohamad E, Ashrafur Rahman SM, Al Mahmud KAH, Habibullah M, Salauddin S (2014) Effect of DLC coating on tribological behavior of cylinder liner piston ring material combination when lubricated with Jatropha oil. Procedia Eng 90:733-739. https://doi.org/10.1016/j.proen g.2014.11.805

14. Rani S, Joy ML, Nair KP (2015) Evaluation of physiochemical and tribological properties of rice bran oil-biodegradable and potential base stoke for industrial lubricants. Ind Crop Prod 65:328-333. https://doi.org/10.1016/j.indcrop.2014.12.020

15. Zulkifli NWM, Azman SSN, Kalam MA, Masjuki HH, Yunus R, Gulzar M (2016) Lubricity of bio-based lubricant derived from different chemically modified fatty acid methyl ester. Tribol Int 93:555-562. https://doi.org/10.1016/j.triboint.2015.03.024

16. Habibullah M, Masjuki HH, Kalam MA, Gulzar M, Arslan A, Zahid R (2015) Tribological characteristics of Calophyllum inophyllum-based TMP (Trimethylolpropane) ester as energysaving and biodegradable lubricant. Tribol T 58:1002-1011. https://doi.org/10.1080/10402004.2015.1025934
17. Arumugam S, Sriram G, Subadhra L (2012) Synthesis, chemical modification and tribological evaluation of plant oil as biodegradable low temperature lubricant. Procedia Eng 38:15081517. https://doi.org/10.1016/j.proeng.2012.06.186

18. Zulkifli NWM, Kalam MA, Masjuki HH, Yunus R (2013) Experimental analysis of tribological properties of biolubricant with nanoparticle additive. Procedia Eng 68:152-157. https://doi. org/10.1016/j.proeng.2013.12.161

19. Zulkifli NWM, Masjuki HH, Kalam MA, Yunus R, Azman SSN (2014) Lubricity of bio-based lubricant derived from chemically modified jatropha methyl ester. J Tribol 1:18-39. https://jurnaltrib ologi.mytribos.org/v1/JT-V1-18-39.pdf. Accessed 2 June 2016

20. Habibullah M, Masjuki HH, Kalam MA, Ashraful AM, Habibb MA, Mobarak HM (2014) Effect of biolubricant on tribological characteristics of steel. Procedia Eng 90:740-745. https://doi. org/10.1016/j.proeng.2014.11.807

21. Shahabuddin M, Masjuki HH, Kalam MA, Bhuiya MMK, Mehat $\mathrm{H}$ (2013) Comparative tribological investigation of biolubricant formulated from a non-edible oil source (Jatropha oil). Ind Crop Prod 47:323-330. https://doi.org/10.1016/j.indcrop.2013.03.026

22. Gulzar M, Masjuki HH, Varman M, Kalam MA, Zulkifli NWM, Mufti RA, Liaquat AM, Zahid R, Arslan A (2016) Effects of biodiesel blends on lubricating oil degradation and piston assembly energy losses. Energy 111:713-721. https://doi.org/10.1016/j. energy.2016.05.132

23. Imran A, Masjuki HH, Kalam MA, Varman M, Hasmelidin M, Al Mahmud KAH, Shahir SA, Habibullah M (2013) Study of friction and wear characteristic of jatropha oil blended lube oil. Procedia Eng 68:178-185. https://doi.org/10.1016/j.proeng.2013.12.165

24. Shahabuddin M, Masjuki HH, Kalam MA (2013) Experimental investigation into tribological characteristics of biolubricant formulated from jatropha oil. Procedia Eng 56:597-606. https ://doi.org/10.1016/j.proeng.2013.03.165

25. Shanta SM, Molina GJ, Soloiu V (2011) Tribological effects of mineral-oil lubricant contamination with biofuels: a pinon-disk tribometry and wear study. Adv Tribol. https://doi. org/10.1155/2011/820795

26. Jayadas NH, Nair KP, Ajithkumar G (2007) Tribological evaluation of coconut oil as an environment-friendly lubricant. Tribol Int 40:350-354. https://doi.org/10.1016/j.triboint.2005.09.021

27. Al Mahmud KAH, Zulkifli NWM, Masjuki HH, Varman M, Kalam MA, Mobarak HM, Imran A, Shahir SA (2013) Working temperature effect of a-C:H/a-C:H and steel/steel contacts on tribo properties in presence of sunflower oil as a biolubricant. Procedia Eng 68:550-557. https://doi.org/10.1016/j.proeng.2013.12.220

28. Md Razak D, Syahrullail S, Yahya A, Mahmud N, Hashim NLS, Nugroho K (2013) Lubrication on the curve surface structure using palm oil and mineral oil. Procedia Eng 68:607-612. https ://doi.org/10.1016/j.proeng.2013.12.228

29. Reeves CJ, Menezes PL, Jen TC, Lovell MR (2015) The influence of fatty acids on tribological and thermal properties of natural oils as sustainable biolubricants. Tribol Int 90:123-134. https:// doi.org/10.1016/j.triboint.2015.04.021

30. Agrawal SM, Lahane S, Patil NG, Brahmankar PK (2014) Experimental investigations into wear characteristics of $\mathrm{M} 2$ steel using cotton seed oil. Procedia Eng 97:4-14. https://doi.org/10.1016/j. proeng.2014.12.218

31. Talib N, Rahim EA (2015) Performance evaluation of chemically modified crude jatropha oil as a bio-based metalworking fluids for machining process. Procedia CIRP 26:346-350. https://doi. org/10.1016/j.procir.2014.07.155

32. Oseni MI, Gundu DT, Enenta AZ (2012) Tribometric evaluation of rubber seed oil lubricant in upset forging. Am J Sci Ind Res 3(5):270-276. https://doi.org/10.5251/ajsir.2012.3.5.270.276

33. Adhvaryu A, Erhan SZ, Perez JM (2004) Tribological studies of thermally and chemically modified vegetable oils for use as 
environmentally friendly lubricants. Wear 257:359-367. https ://doi.org/10.1016/j.wear.2004.01.005

34. Aziz NAM, Yunus R, Rashid U, Zulkifli NWM (2016) Temperature effect on tribological properties of polyol ester-based environmentally adapted lubricant. Tribol Int 93:43-49. https://doi. org/10.1016/j.triboint.2015.09.014

35. Salimon J, Salih N, Yousif E (2012) Triester derivatives of oleic acid: the effect of chemical structure on low temperature, thermo-oxidation and tribological properties. Ind Crop Prod 38:107-114. https://doi.org/10.1016/j.indcrop.2012.01.019

36. Wu X, Zhang X, Yang S, Chen H, Wang D (2000) The study of epoxidized rapeseed oil used as a potential biodegradable lubricant. J Am Oil Chem Soc 77(5):561-563. https://doi.org/10.1007/ s11746-000-0089-2

37. Sripada PK, Sharma RV, Dalai AK (2013) Comparative study of tribological properties of trimethylolpropane-based biolubricants derived from methyl oleate and canola biodiesel. Ind Crop Prod 50:95-103. https://doi.org/10.1016/j.indcrop.2013.07.018

38. Reeves CJ, Menezes PL, Lovell MR, Jen TC (2015) The influence of surface roughness and particulate size on the tribological performance of bio-based multi-functional hybrid lubricants. Tribol Int 88:40-55. https://doi.org/10.1016/j.triboint.2015.03.005

39. Quinchia LA, Delgado MA, Franco JM, Spikes HA, Gallegos C (2012) Low-temperature flow behaviour of vegetable oil-based lubricants. Ind Crop Prod 37:383-388. https://doi.org/10.1016/j. indcrop.2011.12.021

40. Dodos GS, Karonis D, Zannikos F, Lois E (2015) Renewable fuels and lubricants from Lunaria annua L. Ind Crop Prod 75:43-50. https://doi.org/10.1016/j.indcrop.2015.05.046

41. Ing TC, Rafiq AKM, Azli Y, Syahrullail S (2012) Tribological behaviour of refined bleached and deodorized palm olein in different loads using a four-ball tribotester. Sci Iran B 19(6):1487-1492. https://doi.org/10.1016/j.scient.2012.10.027

42. Adhvaryu A, Erhan SZ (2002) Epoxidized soybean oil as a potential source of high-temperature lubricants. Ind Crop Prod 15:247-254. https://doi.org/10.1016/S0926-6690(01)00120-0

43. Alves SM, Barros BS, Trajano MF, Ribeiro KSB, Moura E (2013) Tribological behavior of vegetable oil-based lubricants with nanoparticles of oxides in boundary lubrication conditions. Tribol Int 65:28-36. https://doi.org/10.1016/j.triboint.2013.03.027

44. Sharma BK, Adhvaryu A, Erhan SZ (2009) Friction and wear behavior of thioether hydroxy vegetable oil. Tribol Int 42:353358. https://doi.org/10.1016/j.triboint.2008.07.004

45. Fox NJ, Stachowiak GW (2003) Boundary lubrication properties of oxidized sunflower oil. Lubr Eng 59(2):15-20

46. Martín-Alfonso JE, Valencia C (2015) Tribological, rheological, and microstructural characterization of oleogels based on EVA copolymer and vegetables oils for lubricant applications. Tribol Int 90:426-434. https://doi.org/10.1016/j.triboint.2015.05.004

47. Salih N, Salimon J, Abdullah BM, Yousif E (2017) Thermo-oxidation, friction-reducing and physicochemical properties of ricinoleic acid based-diester biolubricants. Arab J Chem 10:S2273S2280. https://doi.org/10.1016/j.arabjc.2013.08.002

48. Salih N, Salimon J, Yousif E (2011) The physicochemical and tribological properties of oleic acid based triester biolubricants. Ind Crop Prod 34:1089-1096. https://doi.org/10.1016/j.inder op.2011.03.025

49. Sharma UC, Sachan S, Sinha S (2018) Analysis of viscosity-temperature behaviour of karanja oil trimethylolpropane ester biolubricant base stock. Asian J Chem 30(4):790-794. https://doi. org/10.14233/ajchem.2018.20997

50. Sharma UC, Chandra AK, Sachan S (2019) Investigation on thermo-oxidative stability of karanja oil derived biolubricant base oil. Asian J Chem 31(4):839-844. https://doi.org/10.14233 /ajchem.2019.21762

51. Tiong Cl, Azli Y, Abdul Kadir MR, Syahrullail S (2012) Tribological evaluation of refined, bleached and deodorized palm stearin using four-ball tribotester with different normal loads. J Zhejiang Univ-Sci A (Appl Phys Eng) 13(8):633-640. https://doi. org/10.1631/jzus.A1200021

52. Golshokouh I, Golshokouh M, Ani FN, Kianpour E, Syahrullail $S$ (2013) Investigation of physical properties for jatropha oil in different temperature as lubricant oil. Life Sci J 10(8s):110-119. https://doi.org/10.7537/marslsj1008s13.14

53. Rahman MM, Rasul M, Hassan NMS (2017) Study on the tribological characteristics of Australian native first generation and second generation biodiesel fuel. Energies 10(1):55. https://doi. org/10.3390/en10010055

54. McNutt J, He QS (2016) Development of biolubricants from vegetable oils via chemical modification. J Ind Eng Chem 36:1-12. https://doi.org/10.1016/j.jiec.2016.02.008

55. Li W, Wang X (2015) Biolubricants derived from waste cooking oil with improved oxidation stability and low temperature properties. J Oleo Sci 64(4):367-374. https://doi.org/10.5650/jos.ess 14 235

Publisher's Note Springer Nature remains neutral with regard to jurisdictional claims in published maps and institutional affiliations. 